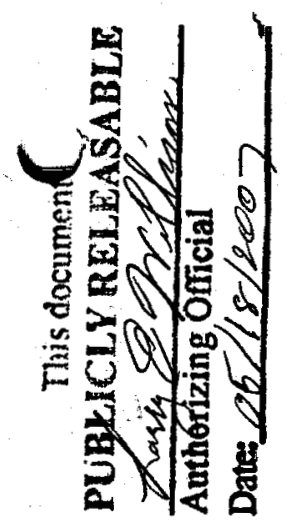

\title{
DRILLING AND TESTING OPERATIONS FOR PROJECT GASBUGGY
}

\author{
By \\ W. G. Cutler and H. L. Kendrick, Members AIME, El Paso Natural Gas Company, \\ Farmington, New Mexico
}

This paper is to be presented at the 43rd Annual Fall Meeting of the Society of Petroleum Engineers of AIME to be held in Houston, Texas on September 29 to October 2, 1968.

\section{ABSTRACT}

This paper deals with mechanics of drilling and testing of the Gasbuggy site wells in the pre-shot and postshot program. The information obtained from pre-shot well drilling and production testing of GB-1 and GB-2 wells confirmed the test site acceptability. The drilling discussion outlines the hole size, casing program, mud and gas drilling requirements, hydrological testing, coring, natural gas flow measurement and logging program.

Hydrological testing of water-bearing strata above the Pictured Cliffs zone was performed to determine the quantity and quality of mobile water that might affect the experiment. The natural gas flow and shut-in well test data obtained while drilling and following completion of each well are presented. The mechanics of emplacement hole drilling, casing, loading and stemming for shot containment are discussed.

Following the detonation of the device on December 10,1967 the re-entry into the emplacement hole for preliminary sampling and chimney height determination is described. Post-shot pressure build-up data and gas sampling procedures are described. The re-entry drilling into GB-2R is described and the latest available test data relative to the flow rates and pressure data are presented.

\section{INTRODUCTION}

Project Gasbuggy moved from a four-year planning stage to the site confirmation stage immediately following the signing of a contract by the Atomic Energy Commission, the Department of the Interior, and El Paso Natural Gas Company for the jointly sponsored project on January 31, 1967. Obtaining test site confirmation was the first order of business and the first well, GB-1, was spudded on February 11, 1967.

The purpose of GB.? was (1) to evaluate the waterbearing strata above the Pictured Cliffs zone for quantity and quality, (2) to evaluate the natural gas flow and shutin pressure data of the objective Pictured Cliffs reservoir and (3) to obtain formation properties for reservoir evaluation of the gas-bearing Pictured Cliffs zone and associated formations.
A producing Pictured Cliffs well drilled in 1956 was located 330 feet from the proposed GB.I location. This well, the San Juan 29-4 Unit No. 10, was drilled and completed with 9-5/8-inch surface casing set at 124 feet, 5-1/2-inch production casing set in a mud-drilled 8-3/4inch hole through the Pictured Cliffs formation to 4203 feet. The well was selectively perforated, sand-water fractured and completed with 2-inch tubing. The well's calculated open flow at the end of a three-hour blow down through a $3 / 4$-inch choke was $1400 \mathrm{Mcfd}$. The initial deliverability to the pipeline was $60 \mathrm{Mcfd}$ at 50 percent of the wellhead shut-in pressure. The original bottom hole pressure was calculated to be $1230 \mathrm{psig}$ at 4156 feet with a reservoir temperature of $130^{\circ} \mathrm{F}$. This we 11 produced 81,854 Mef from initial production in 1957 to the time it was shut in during October, 1967.

\section{GB-! WELL PROGRAM}

The drilling program for $G B-1$ consisted of setting 13-3/8-inch surface casing at 502 feet. A conventional 12-1/4-inch hole was mud-drilled to a depth 45 feet above the Ojo Alamo formation. From this point diamond coring with an 8-3/4-inch by $5-1 / 4$-inch core bit was initiated and the upper portion of the Ojo Alamo was cored and swab tested under a packer to determine the rate of water entry. The lower portion of the Ojo Alamo was also cored and similarly tested. Results of each test indicated a low mobility water factor and a water quality not suitable for domestic use.

Coring was continued to the casing point above the Fruitland formation and after the cored hole was reamed 9-5/8-inch casing was run and cemented at 3755 feet. Full hole $8-3 / 4$-inch by $5-1 / 4$-inch coring with gas circulation was initiated immediately below the casing to the top of the Pictured Cliffs where the core hole size was reduced to 6-1/4-inch and continued to the well's total depth of $\$ 320$ feet, or 120 feet into the L e wis shale. A total of 870 feet of continuous coring was performed with a core recovery of $\$ 8$ percent. Throughout the gas coring operation natural gas flow gauges were recorded at each drill pipe connection and when the core barrel was pulled. Figure 1 illustrates the natural gas flow data secured during the coring operation. 


\section{DISCLAIMER}

This report was prepared as an account of work sponsored by an agency of the United States Government. Neither the United States Government nor any agency Thereof, nor any of their employees, makes any warranty, express or implied, or assumes any legal liability or responsibility for the accuracy, completeness, or usefulness of any information, apparatus, product, or process disclosed, or represents that its use would not infringe privately owned rights. Reference herein to any specific commercial product, process, or service by trade name, trademark, manufacturer, or otherwise does not necessarily constitute or imply its endorsement, recommendation, or favoring by the United States Government or any agency thereof. The views and opinions of authors expressed herein do not necessarily state or reflect those of the United States Government or any agency thereof. 


\section{DISCLAIMER}

Portions of this document may be illegible in electronic image products. Images are produced from the best available original document. 
A short duration, 18-hour, pressure build-up test was conducted when coring reached the top of the Pictured Cliffs. A natural gas flow rate of 100 Mcfd was measured for the Fruitland $\mathrm{z}$ one immediately prior to shutting in the well.

At total depth the cored interval was reamed to 8-3/4-inches. A series of dry hole $\log s$, directional surveys, borehole photos and packer flow meter surveys were completed prior to running the 2 -inch production tubing. Flow testing was resumed following a seven-day shut-in period with an isochronal type test being conducted with six-hour flow periods at rates of 90, 440, 275, and 146 Mcfd.

After a review of the data obtained during the drilling and the initial testing of GB-1 the technical representatives of the participating organizations recommended, and secured, site acceptability.

\section{GB-2 WELL PROGRAM}

Immediately after site acceptance the GB-2 well was commenced to confirm the continuity of data obtained from GB-1. The well was located 470 feet from GB-1 and 300 feet from the proposed emplacement hole location. The relative well locations are shown in Figure 2.

Surface 9-5/8-i nch casing was set at 496 feet, and an 8-3/4-inch hole was mud-drilled through the Ojo Alamo formation where a hydrological swab test was conducted in a similar manner as employed in GB-1. Drilling was resumed to the casing point at the Fruitland-Pictured Cliffs c ontact where 7 -inch casing $w$ a s run and cemented at 3920 feet.

Below the casing a 6-1/4-inch by 3-1/2-inch gas coring program was pursued to total depth of 4260 feet. Mud or water entry, attributed to drilling the naturally fractured upper Pictured Cliffs with mud prior to running casing, necessitated remedial cement squeeze operations at the c a sing seat after reaching 4046 feet before successful gas coring could be accomplished to total depth. As in GB-1, natural gas gauges were taken with eachdrill pipe connection and trip with the core barrel. The flow rates ranged from 4 to $43 \mathrm{Mcfd}$ in the cored interval. Three $\mathrm{h} u \mathrm{ndred}$ forty feet were cored with a 92 percent core recovery.

A series of dry hole $\log s$, directional surveys, borehole c a mera, packer flow meter and bottom hole fluid sampler runs and surveys preceded the landing of 2-inch production tubing, completing the well.

\section{PRE-SHOT TESTING}

A shut-in pressure build-up test of GB-2 was initiated and continued for nine weeks before the well was b lown, without restriction, for eight days to a rate approaching stabilization \& $4 \mathrm{Mcfd}$. The we 11 was again shut in and pressure build up recorded until the hole was mudded up, wet hole log g ing completed and the well stemmed for shot containment.
A s e c ond GB-1 isochronal type test was initiated after drilling GB-2 and was conducted using six-hour flow intervals at rates of 415, 264, 148 and $75 \mathrm{Mcfd}$, with the last rate being continued for 30 .days. ${ }^{1}$ A third flow test was later made in which the well was produced at regulated surface rates to achieve a constant reservoir volume withdrawal. The surface rate was regulated from $738 \mathrm{Mcfd}$ initially to 94 Mcfd at the conclusion of the 6-day period.

Figure 3 shows the wellhead pressures of GB-1 and San Juan 29-4 Unit No. 10 and the interference recorded between these wells. Immediately prior to final logging and stemming for shot containment the GB-1 well was produced through a $3 / 4$-inch choke for five days. The rate was measured at 447 Mcfd at the end of three hours and 35 Mcfd at the end of the five days. Pressure interference between GB-1 and GB-2 was not observed during this period.

\section{THE EMPLACEMENT HOLE}

The drilling of GB-E, the nuclear device emplacement hole, was started on June 25, 1967. A dry ho 1e digger was employed prior to assembling the drilling rig to set 30 -inch surface casing at $49 \mathrm{f}$ eet. A 13-3/4-inch pilot hole was drilled to a depth of 4350 feet and subsequently reamed from a $13-3 / 4$-inch to 28 -inch hole diameter employing both platform $\mathrm{re}$ a m er $\mathbf{s}$ and conventional pilot and string reamers. Specially fabricated casing of 20 -inch O. D. was run to a de pth of 4324 feet. The pipe was cemented in a conventional oil field manner in three stages. The first stage employed float shoe, float collar and a baffle collar arrangement, while the second stage was placed through a cement collar at 3550 feet. The third stage used a cement collar at 1800 feet. In excess of 19,000 cubic feet of cement slurry was used in cementing. The 20-inch casing was designed to prevent collapse, assuming that the casing would be dry at the time of device emplacement. Reinforcing bands were added a 5 and 6 foot intervals on the bottom 1460 feet of the casing to achieve the desired collapse design factor.

The 20-in ch casing from the surf a ce to 2400 feet weighed 130 pounds per foot with a wall thickness of .64 inch. The balance of the casing weighed 160 pounds per foot with a wall thickness of .77 inch. While cementing, the stage c o 11ar at $\mathbf{3 5 5 0}$ feet was not closed and later permitted Ojo Alamo water to leak into the casing. It was decided to run the device with water in the casing rather than risk sque e ze cementing the stage collarports.

The nuclear device canister, shown in Figure 4, was moved over the emplacement hole with a crane and later lowered into the 20 -inch cased hole on 7 -inch casing. The firing cable is shown extending from above the canister and running over the rounded crutch which was used to prevent damage to the cable.

One joint of the 7-inch cas ing, noted in Figure 5, was made up on the top of the canister and lowered into the hole. After skidding the rig over the emplacement hole the device was lowered on the 7-inch casing to a depth 
of 4240 feet. Some $13 \mathrm{c} \mathrm{a} \mathrm{b}$ le s to the device and various instruments were supported with clamps between the centralizer blades positioned on every other casing joint and and wer e taped to the casing to minimize damage while lowering.

\section{STEMMINGOPERATIONS}

The slotted joints of $\mathrm{c}$ a s in $\mathrm{g}$ were run at predetermined depths to permit placement of the cement used for the stemming operation. Tubing was run inside the 7 -inch casing and the cement mixture pumped through these slots to fill the annulus between the 7-inch and 20-inch casing. Three s t a ge s of cement were placed from 4228 feet to 3000 feet, $10 / 80$ mesh sand was placed from 3000 feet to 2500 feet, cement from 2500 feet to 1500 feet, and sand to within 50 feet of the surface. A chemical grout of 750 gallons was pumped into the top 50 feet of the 20 -inch casing.

Figure 6 diagrams the stemming of GB-E, GB-2, San Juan 29-4 Unit No. 10, and the placing of instruments and stemming of GB-1 following the completion of preshot production testing and the mudding up of the dry hole sections for wet hole $\log$ s and surveys. GB-1 was equipped with instruments and stemmed in the same operation. The instruments and cables were attached to 1520 feet of 2-3/8-inch fiberglass tubing and lowered into the hole to $4250 \mathrm{f}$ ee $\mathrm{t}$ on conventional st e e 1 tubing. Cem e $\mathrm{nt}$ was pumped through the tubing string into the open hole section and the $9-5 / 8$-inch by $2-3 / 8$-inch tubing annulus from 4250 feet to 3000 feet. Drilling mud stemmed the balance of the hole to the surface.

The San Juan 29-4 Unit No. 10 was stemmed by the use of sand placed in the bottom of the hole opposite the perforated intervals and a bridge plug set above the sand at 3880 feet. Cement was then p la ced from the bridge plug to 2940 feet and the balance of the casing was filled with mud to the surface. GB-2 was stemmed with cement from 4220 feet to 3000 feet and the balance of the hole was filled with drilling mud.

\section{OFFSET WELL PERFORMANCE}

Prior to detonation, the seve $\mathrm{n}$ gas wells within a 1-1/4-mile radius of ground zero were shut in for pressure build-up study. Short 1y before detonation, bottom hole pressure bombs were placed in three of these wells and surface pressure recording instruments we re placed on three other wells. The charts from these recording instruments only indicated a fluctuation of the stylus at the ti me ground shock reached each instrument and the rate of pressu re build-up in each well remained apparently unaltered at the time of the detonation and thereafter. No physical damage was found to have occurred to any of the field wells or their surface equipment.

\section{RE-ENTRY OPERATIONS}

Re-entry drilling operations were initiated in the emplacement hole on December 13, following the detonation on December 10,1967. ${ }^{2}$ The program consisted of drilling out the sand and cement used to contain the explosive inside the 7 -inch casing. Gas was used as the circulating fluid to a depth of 3300 feet, but was changed to a treated water when the cement became sufficiently moist to preclude further gas drilling. It was determined that wate $r$ was entering the wellbore through the 20-inch stage collar at a depth of 3550 feet. The rate of influx water was determined to be two cubic feet per hour.

At a depth of 3858 feet a six-foot void was encountered and circulation was lost. No radioactivity was encountered. The fluid level was determined to be standing at a depth of 1750 feet from the surface. Dri 11 ing was resumed without the establishment of circulation and on January 10, 1968 a $\mathrm{n}$ in e-foot void was encountered at a depth of 3907 feet. The bit appeared to have encountered metal at a depth of 3916 feet and drilling operations were discontinued. Shortly thereafter radioactive Xenon gas was detected at the surface and the wellhead pressure increased to $833 \mathrm{psi}$. The drill pipe utilized to drill down to this depth was stripped out of the hole and 2-1/2-inch tubing was 1anded at 3792 feet $\mathrm{through}$ a production packer set at 3786 feet. A diagram of the completed ree ntry wells, GB-ER and GB-2RS, is shown in Figure 7.

Small volumes of gas were taken from the well in order that the gas samples could be collected for laboratory analysis. Pressure measurements were made during these short flow intervals. ${ }^{2}$

Re-entry drilling into the Gasbuggy No. 2 well was initiated in June, 1968. During the re-entry operations it was found that the well could not be entered to the total depth due to obstructions in the casing at 3704 feet and 3812 feet. A window was milled in the casing at $3691 \mathrm{feet}$ and a sidetrack hole was gas-drilled to a new total depth of 4600 feet. During this re-entry drilling operation, gas flow measurements were made each time drill pipe connections and trips were made. Production tubing was landed in the uncased hole at 4224 feet after logging and survey operations were completed. Figure 8 illustrates the gas flow data secured while drilling the post-shot sidetrack hole and also shows a comparison of pre-shot flow measurements obtained from GB-2.

\section{POST-SHOT TESTING}

Production testing on the re-entry emplacement well, GB-ER, started on June 28, and consisted of producing the well at a rate of five million cubic feet per day for six days, shutting the well in one day for bottom hole pressure and temperature measurement, and resuming the five $\mathrm{m}$ i 11 i o $\mathrm{n}$ cubic feet per day flow rate for five days. The well was then shut in briefly for bottom hole pressure and temperature measurement, then reopened at a rate of 0.75 million cubic feet per day for four days with bottom hole pressures and temperatures being measured. The well was then shut in for pressure build up measurements which are still continuing. Figure 9 relates the surface wellhead and bottom hole pressure data for this test series. 
At the beginning of the test the s u r f a c e wellhead pressure was $942 \mathrm{psig}$ and the bottom hole pressure was 1067 psig with a temperature of $118^{\prime \prime} \mathrm{F}$. All of the bottom hole pressure and temperature measurements in the emplacement hole were made at a depth of 3790 feet. The normal Pictured Cliffs reservoir temperature at 4050 feet is $130^{\prime} \mathrm{F}$. During the initial six-day flow period 28.93 MMcf of gas were produced. Just prior to the 24-hour shutin period the flowing pressure was measured at $585 \mathrm{psig}$ with a wellhead temperature of $146 " \mathrm{~F}$. At the beginning of the 24-hour shut-in period the wellhead pressure was recorded at 821 p sig with a bottom hole pressure of 906 psig at $248^{\circ} \mathrm{F}$. and at the end the wellhead pressure was recorded at $819 \mathrm{p} \mathrm{s}$ i g with a bottom hole pressure of 917 psig at 174" F. During the next 5-doy flow period 25.13 MMcf of gas were produced with a flowing pressure measured at the end of the period of 328 psig and a flowing temperature of $153^{\circ} \mathrm{F}$. The shut-in wellhead pressure at the end of this period was 709 psig with a bottom hole pressure of $780 \mathrm{psig}$ and 247 " F. During the next four days $2.98 \mathrm{MMcf}$ of gas were produced with a flowing pressure at the end of the period of 575 psig at 84 " F. The wellhead pressure one hour after closing the well was 718 psig with a bottom hole pressure of 798 psig at $227^{\circ} \mathrm{F}$. The bottom hole pressure at the time the well was shut in was measured at $793 \mathrm{psig}$ at $241^{\circ} \mathrm{F}$. Twenty-four hours after discontinuing flow the wellhead pressure was measured at 723 psig at the time the bottom hole pressure was $814 \mathrm{psig}$ at $174^{\circ} \mathrm{F}$. After 52 days' pressure build up, on $\mathrm{S}$ e p te m ber 4, 1968, the wellhead pressure measured 812 psig with a bottom hole pressure of $916 \mathrm{psig}$ at $118^{\circ} \mathrm{F}$.

Figure $10 \mathrm{show}$ s the recorded wellhead and bottom hole temperatures m easured on GB-ER throughout this test period. The wellhead pressure curve is shown to relate the temperature curves with flow sequence.

During the flow tests conducted on GB-ER pressures were measured on GB-2RS which indicate communication existed between the two wells. Figure 11relates the wellhead pressures measured on GB-ER and GB-2RS.
The three f low tests attempted in mid-July for GB2RS were hindered by the apparent caving of the re-entry hole after tubing was run. Perforating the tubing from 4052 feet to 4062 feet failed to establish normal communication between the annulus and the tubing needed to obtain a representative test.

Figure 12 summarizes the results of the gas analyses obtained from GB-ER during the post-shot testing. The change in sample composition with production reflects a decrease in carbon dioxide and hydrogen while the methane and other hydrocarbons increased. This is interpreted as evidence of uncontaminated reservoir gas e $\mathrm{ntry}$ into the chimney.

No further flow tests have been conducted on the emplacement hole or the GB-2RS well but pressure build up data is being recorded at this time.

\section{REFERENCES}

1. Atkinson, Charles H. and Ward, Don C.: "Project Gasbuggy-Status Report", J. Pet. Tech., October, 1967, p. 1323.

2. Holzer, F. "Gasbuggy Preliminary Post-Shot Summary Report", Lawrence Radiation Laboratory, Report No. PNE 1003, January, 1968, pp. 9-12.

\section{ACKNOWLEDGMENT}

Project Gasbuggy is a joint effort under the U. S. A tom ic Energy Commission's Plowshare Program by El Paso Natural Gas Company, the Bureau of Mines of the U. S. Department of Interior and the Atom i c Energy Commission with te chnical assistance provided by Lawrence Radiation Laboratory, Livermore, California. This report was prepared as a part of project performance.

\section{LEGAL N I TICE}

This report was prepared as an account of Government sponsored work. Neither the United States, nor the Commission. nor $m$ y person 20 ting on behalf of the Com xission:

A. Sakes any warranty or represeataton, expressed or implied, with respect to the accuracy. completeness. or usefulness of the information contained in this report. or that the use of my information, apparatus, method. or process dlaclosed in this report may not infringe privately owned rigats; or

B. Assumes any liablittea with respect to the ase of. or for damages resuiting from the of $m y$ informstion, apparatus, method, or process disclosed in this report.

As und in the above, "pereon acthe o behalf of the Cod this As used in the above, "person acting as behalf of the Commission" Includes my em ployee or contractor of the Commission. Or employee of such contractor. to the extent that such employee contractor of the Connission, or employee of Nch contractor prepares, disseminates, or provides access to, my Infornutionpursuant to his employment or contract with the comolsiston, or bis employment with such contractor. 


\section{GASBUGGY NO. I \\ NATURAL GAS ROW RATES}

WHILE COFE DRILLING

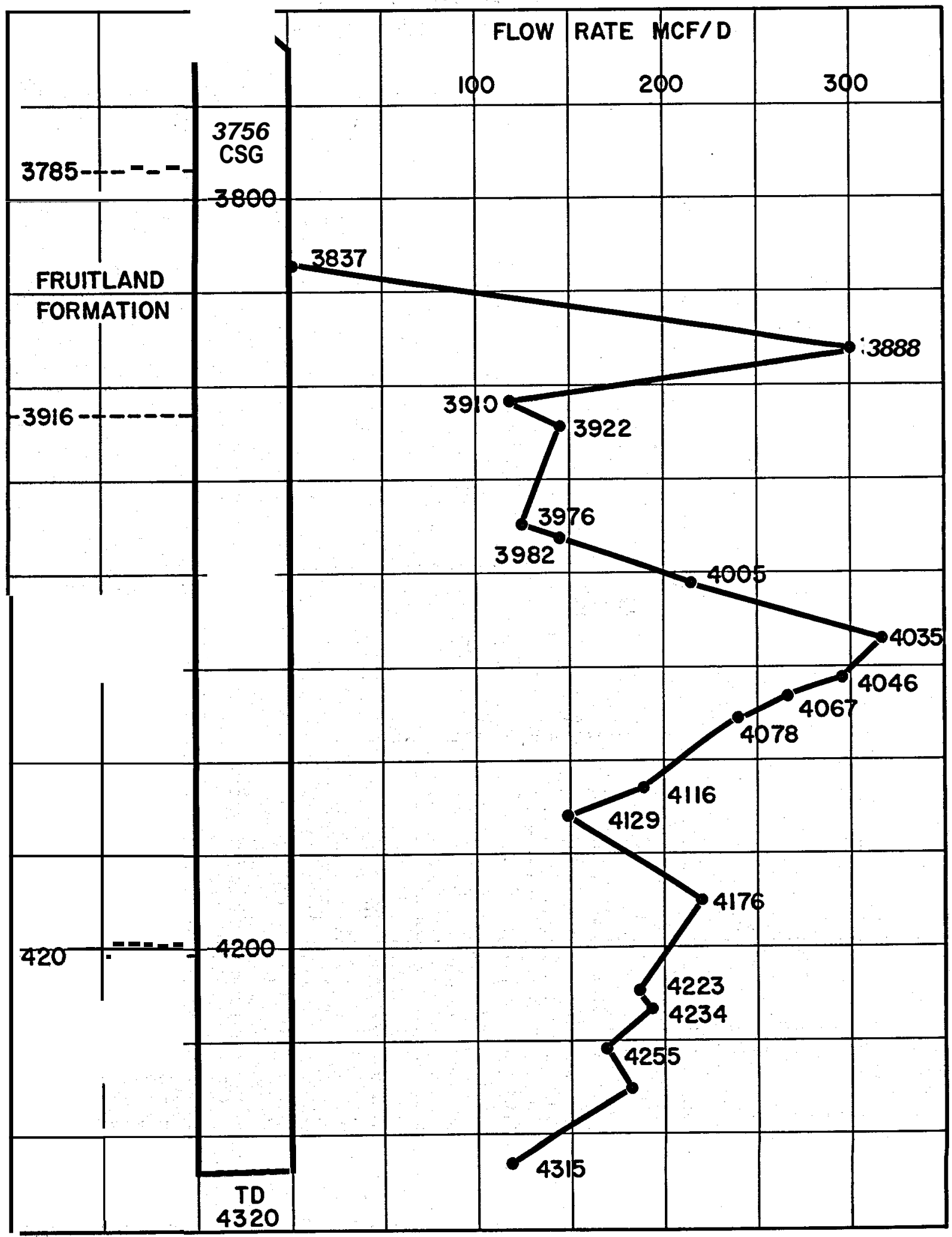

Figure 1 


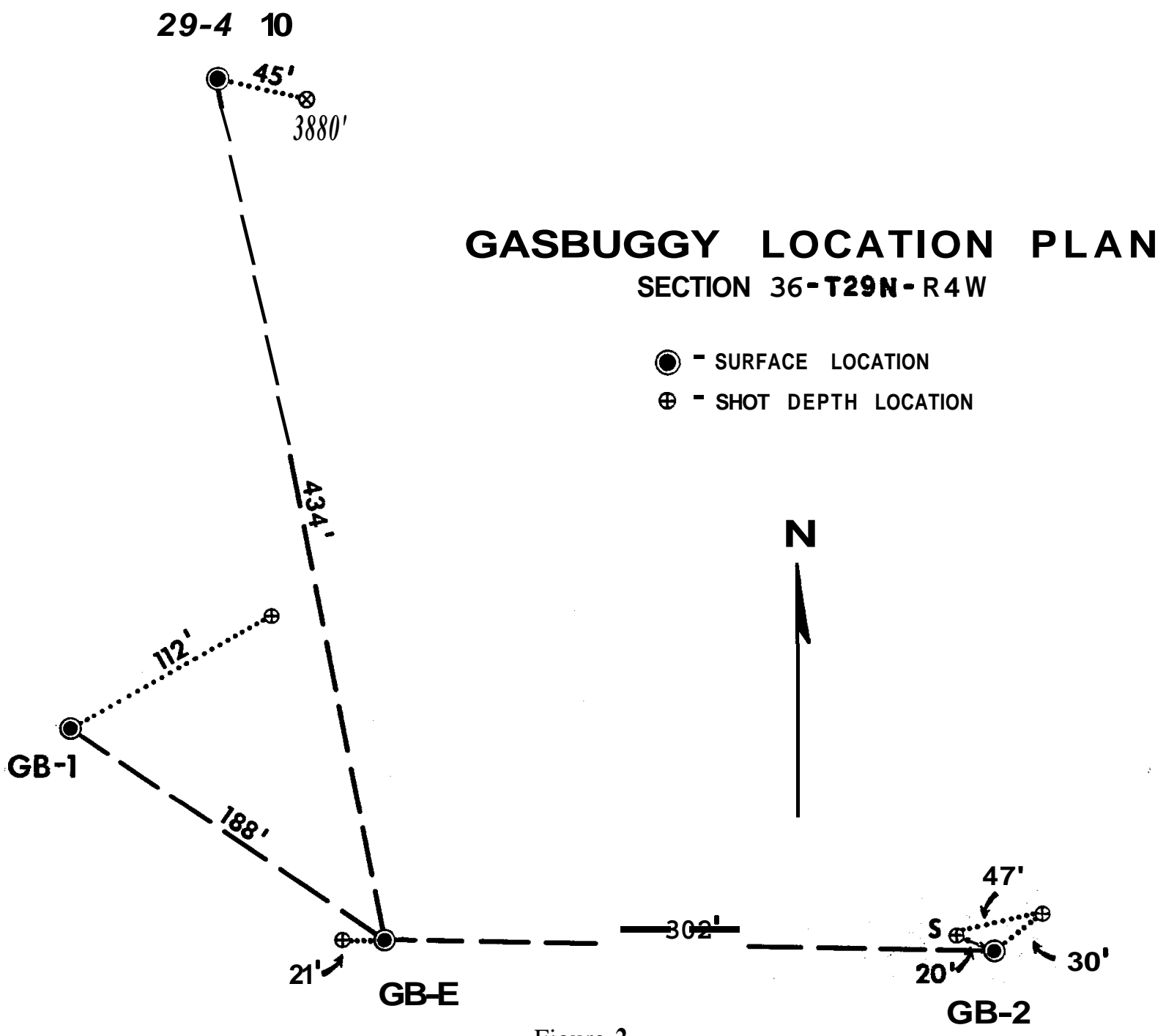

Figure 2

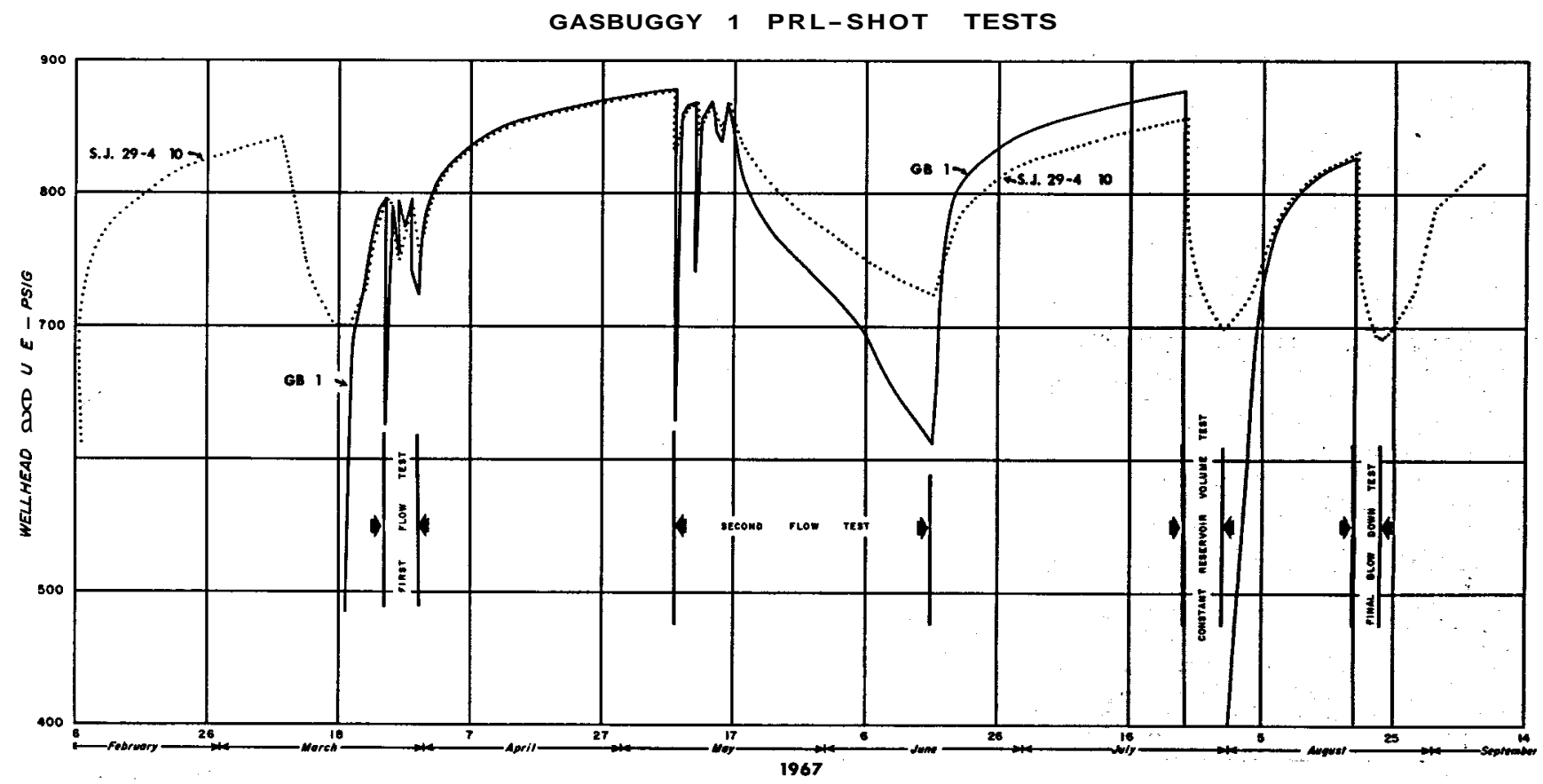

Figure 3 


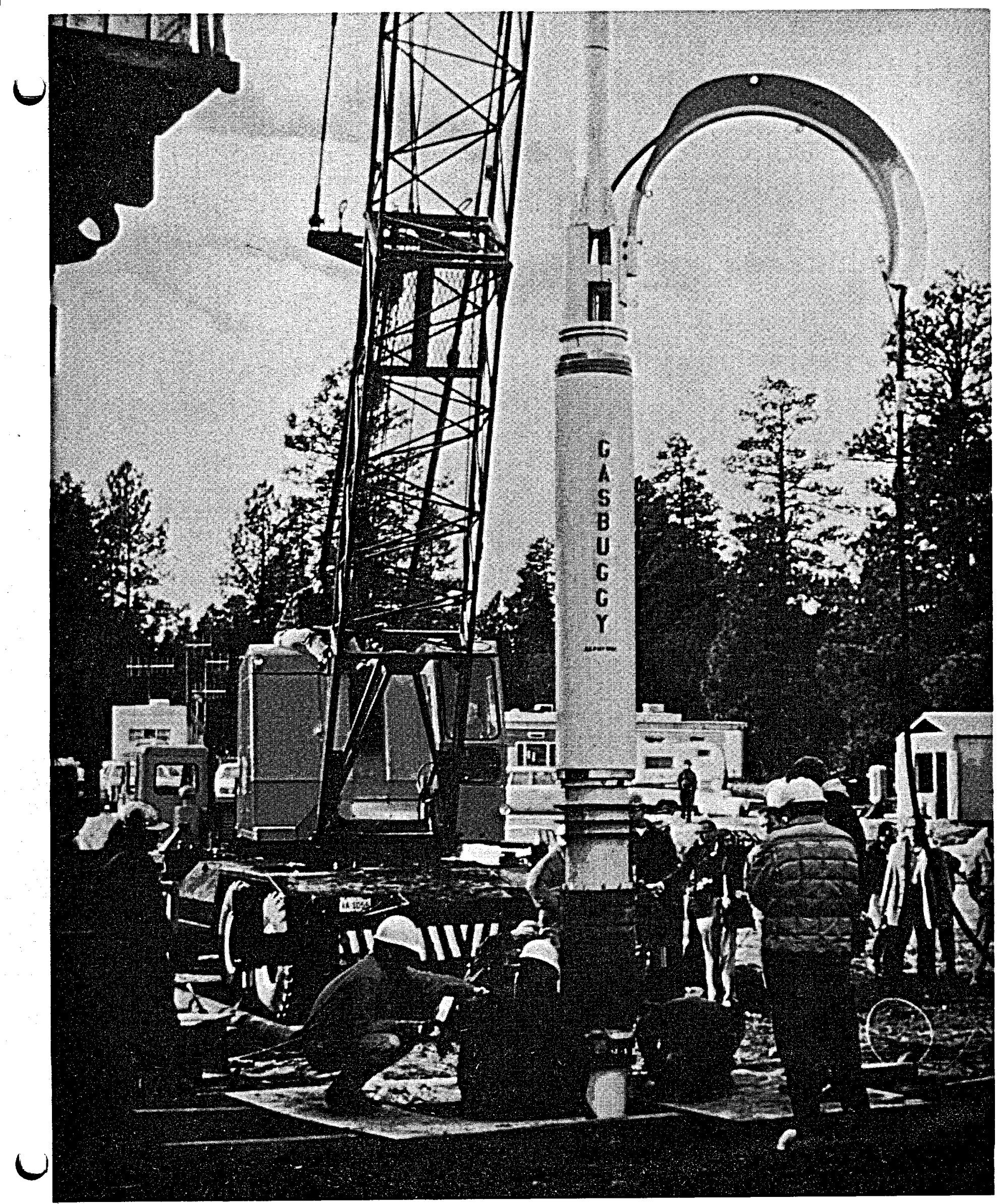

Figure 4 


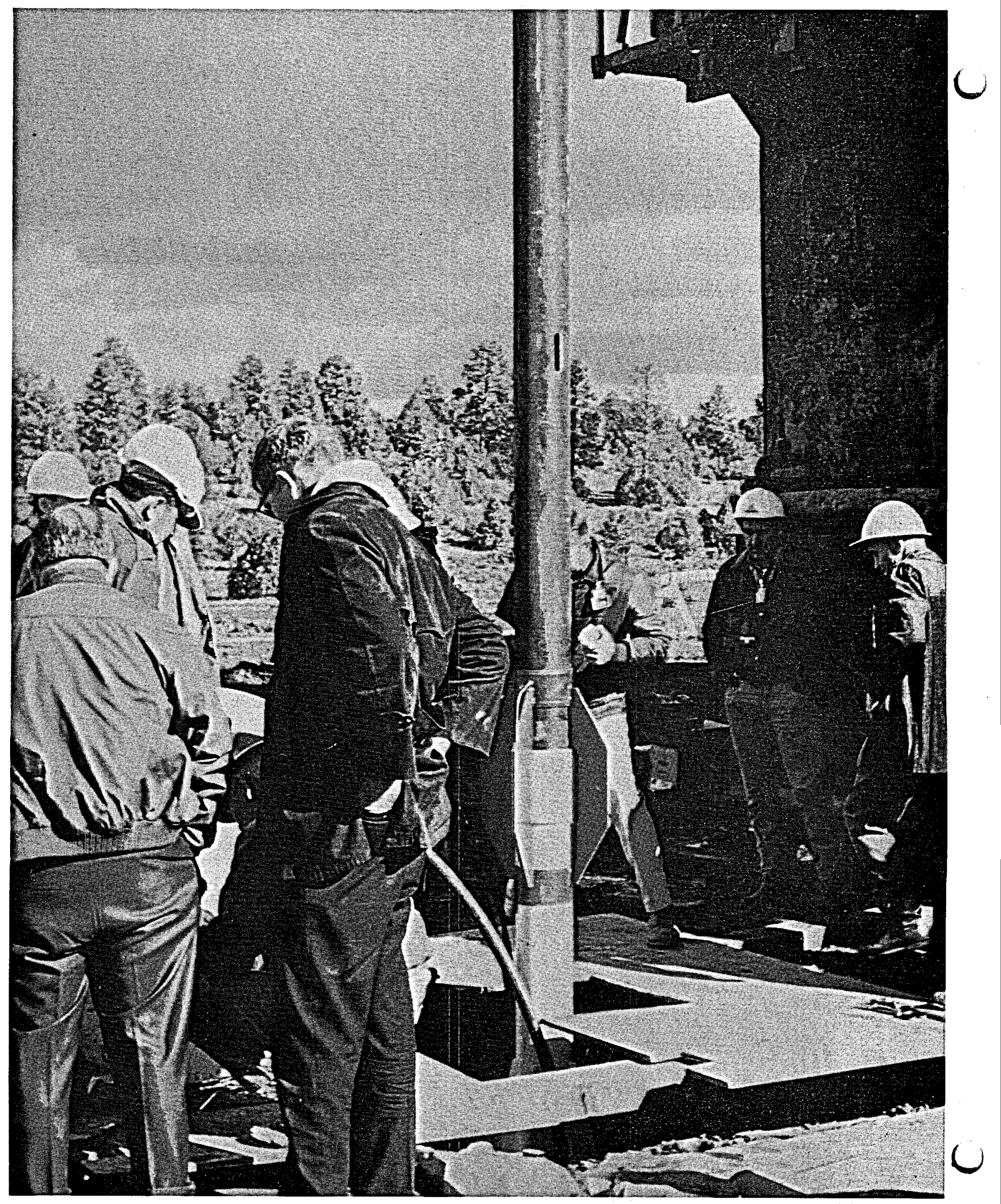


GASBUGGY STEMMING

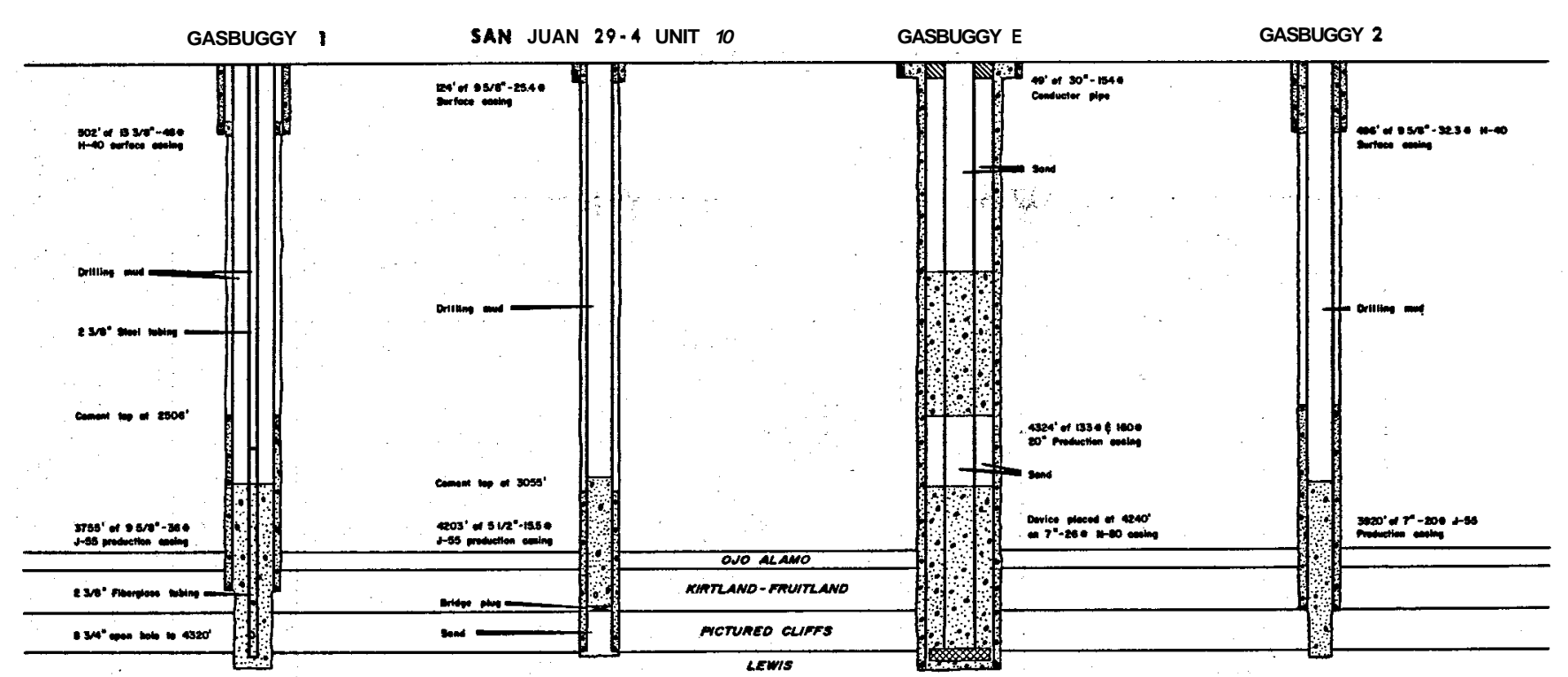

Figure 6

\section{POST SHOT RE-ENTRY}

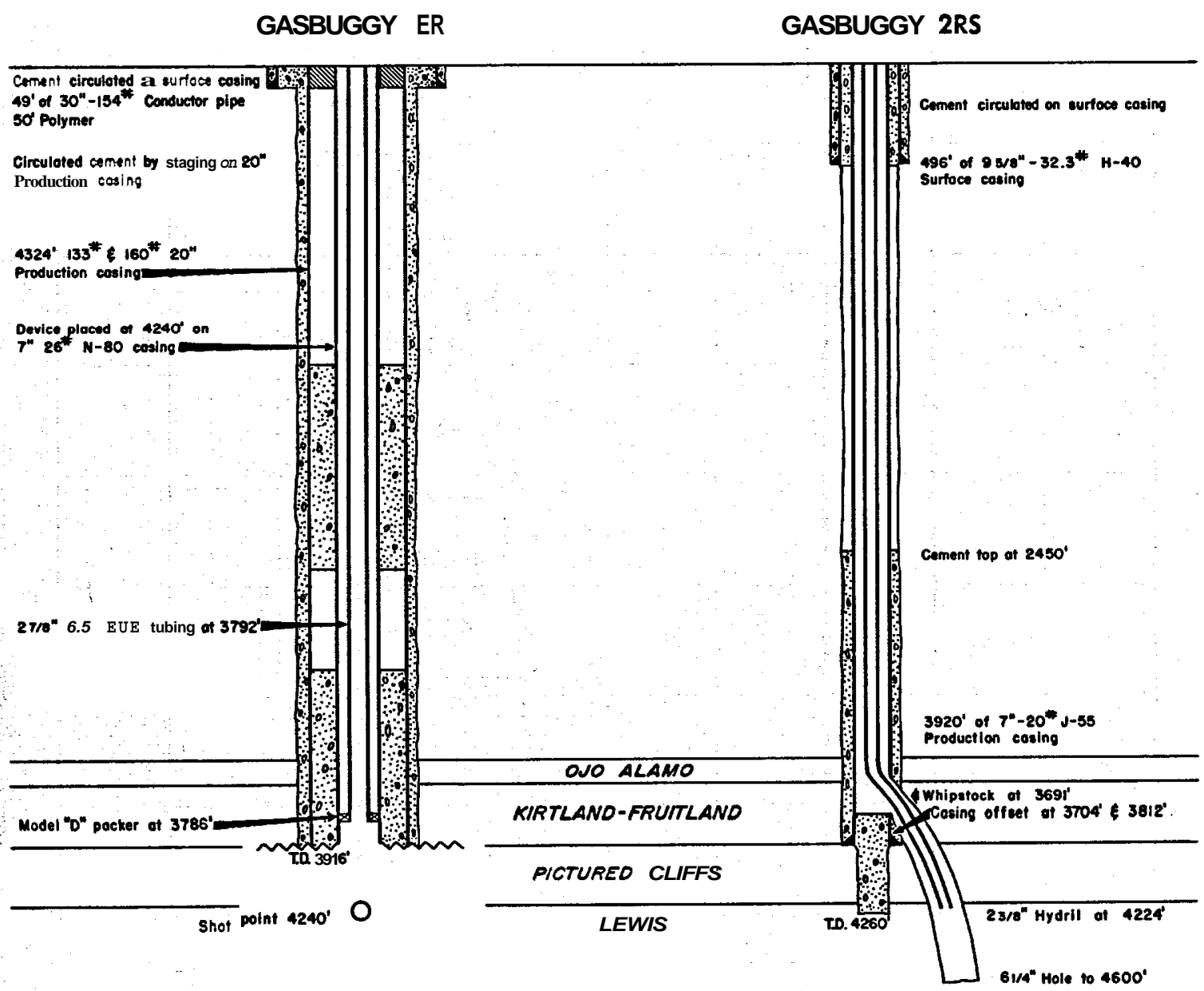

Figure 7 
GASBUGGY NO. 2 R S

NATURAL GAS FLOW RATES

WHILE DRILLING

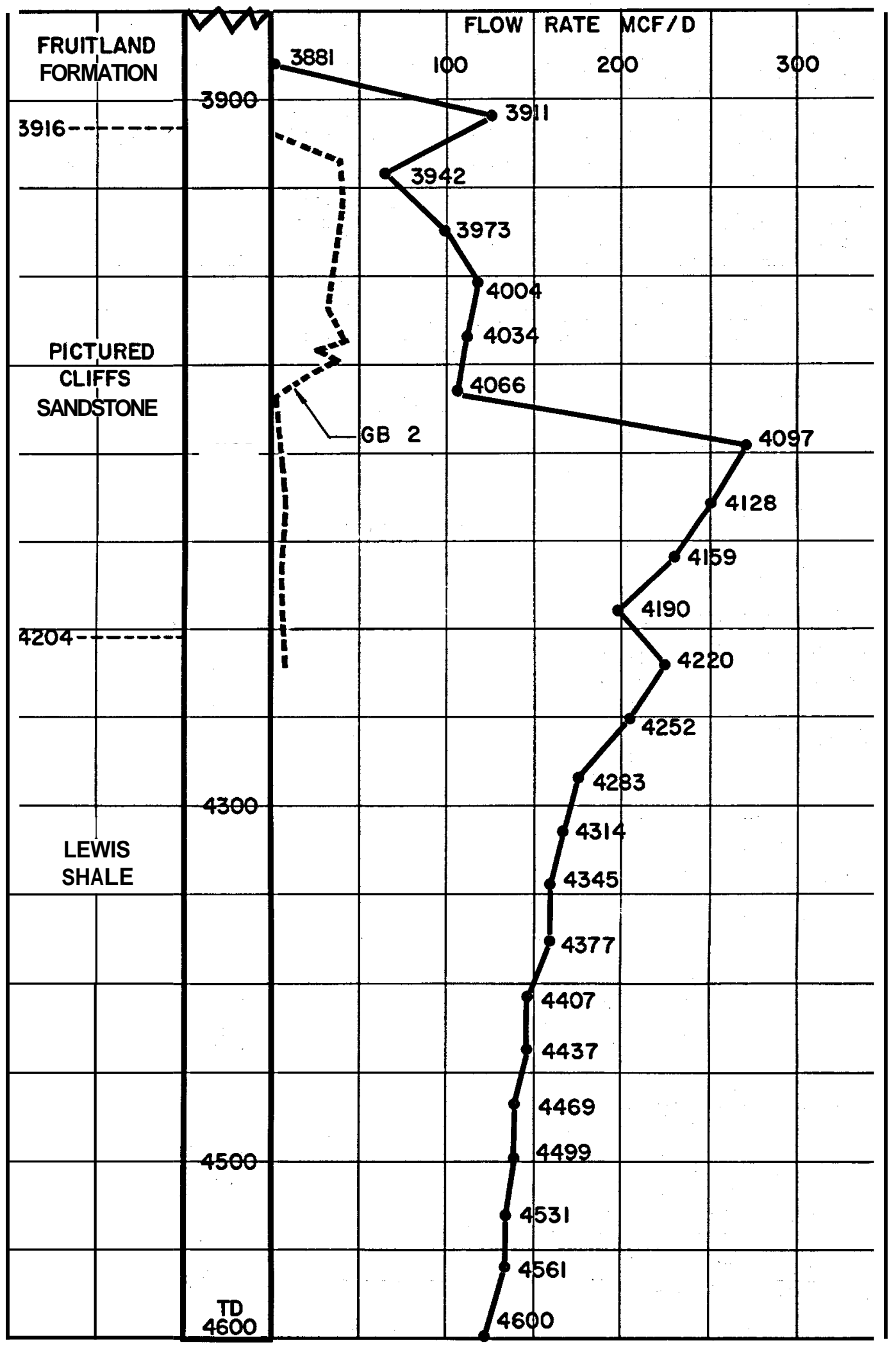

Figure 8 


\section{GASBUGGY ER}

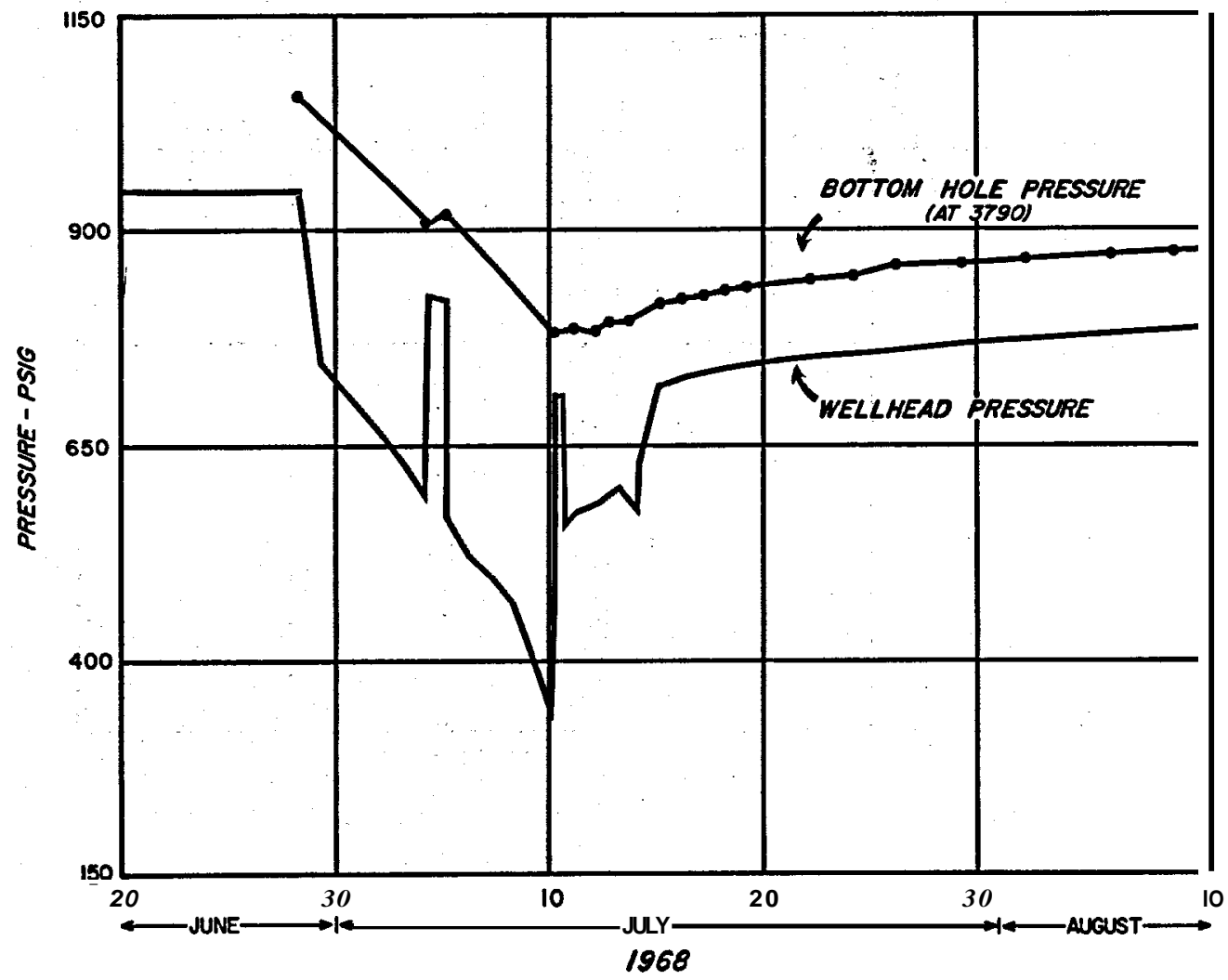

Figure 9

GASBUGGY ER

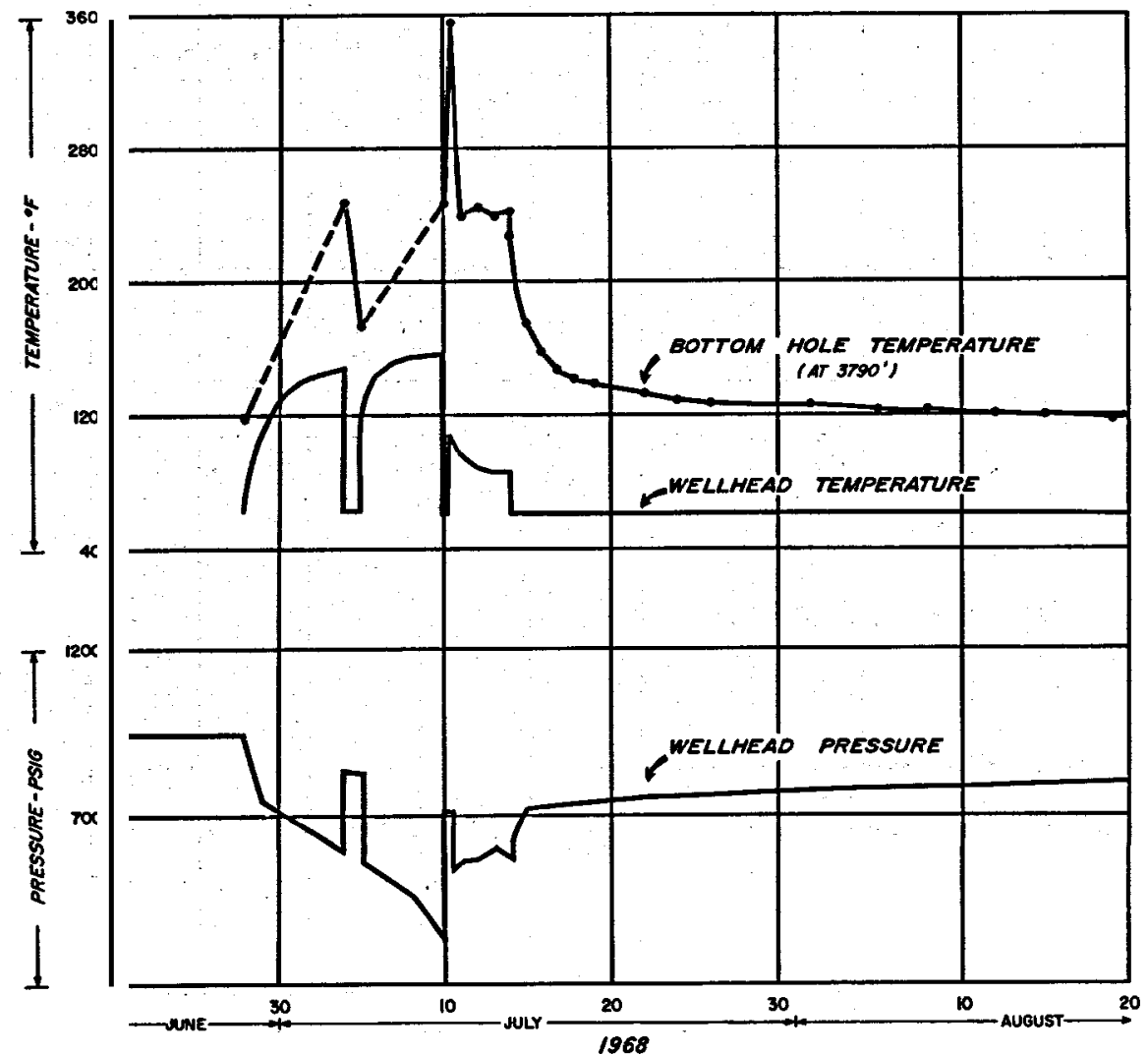

Figure 10 
POST SHOT TESTS

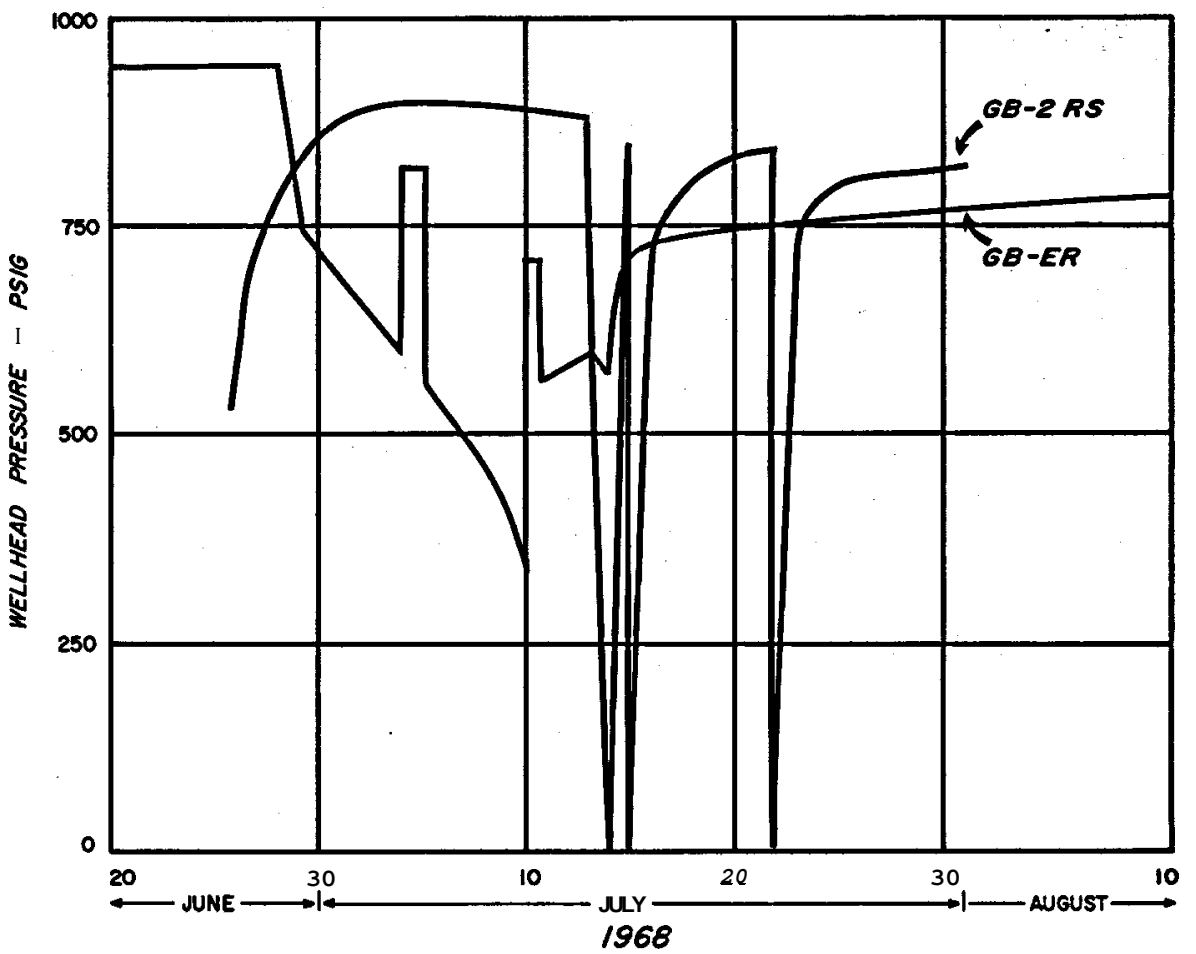

Figure 11
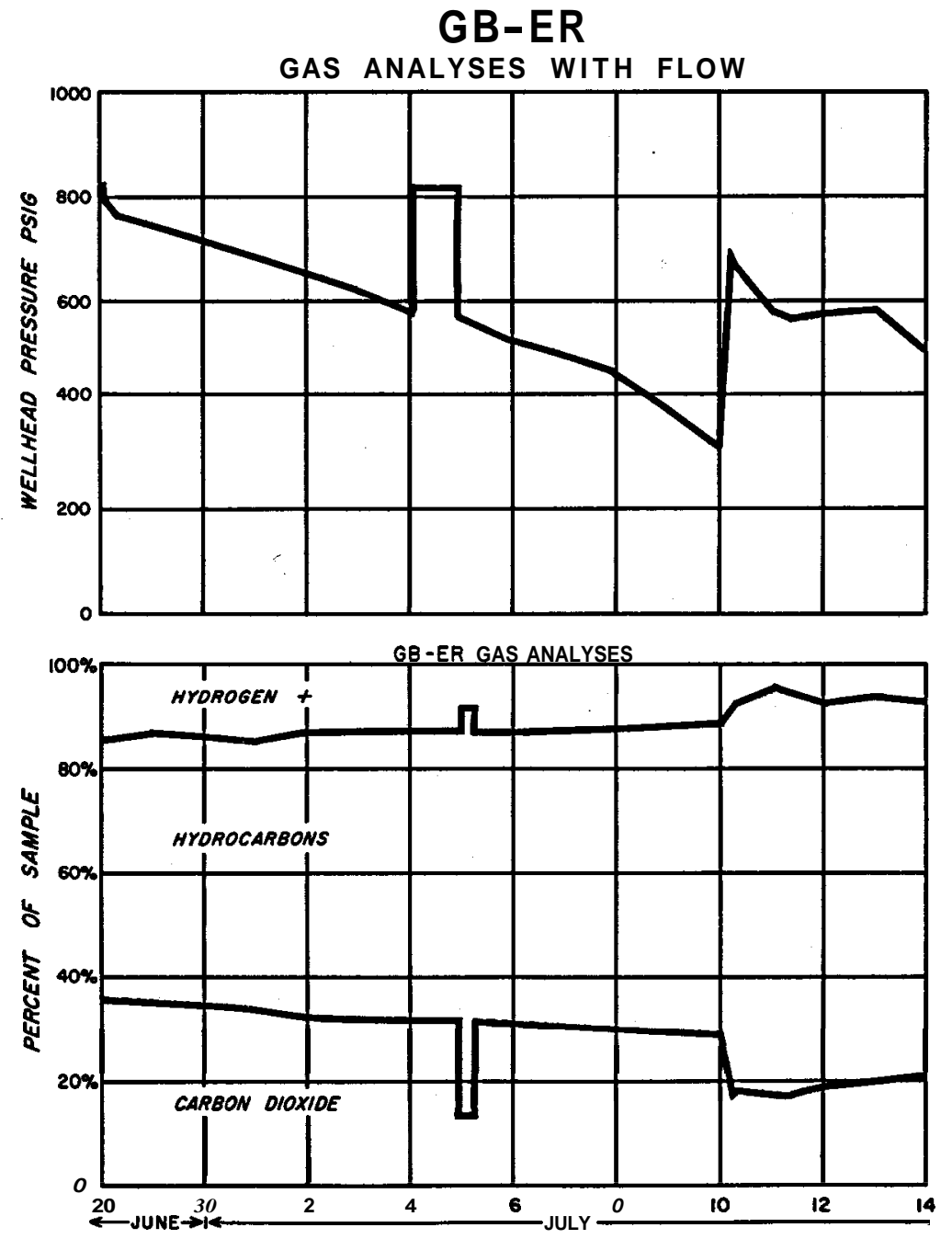

Figure 12 